\title{
FOREIGN INCOME - PROBLEMS OF DOUBLE TAXATION
}

\author{
${ }^{I}$ Tetiana Yarotska, $P h D$; \\ ${ }^{2}$ Svitlana Fedchuk, PhD; \\ ${ }^{1}$ Senior researcher at the Scientific Institute of Fiscal Policy of the National University of State Fiscal \\ Service of Ukraine; \\ ${ }^{2}$ Head of Department of the Scientific Institute of Fiscal Policy of the National University of State \\ Fiscal Service of Ukraine
}

DOI: https://doi.org/10.31435/rsglobal_ijite/30112018/6210

\section{ARTICLE INFO \\ Received 23 September 2018 Accepted 16 November 2018 Published 30 November 2018 \\ KEYWORDS \\ personal income tax, credit of foreign tax, double taxation of income, confirmation of foreign tax base and tax payment, exchange of information in tax matters.} \begin{abstract}
The article highlights implications of foreign income taxation of Ukrainian tax residents. Based on the effective Tax Conventions on Income and on Capital, individuals can claim a credit of tax paid abroad against their Ukrainian tax due. However, the claim must be supported by a specific document prescribed by Ukrainian legislation. In practice, the obtaining of the proper document from foreign tax authorities may be impossible for taxpayers, bringing the double taxation of personal income. Thus, the options of improvement of tax credit mechanism and unification of official confirmation of tax base and tax payment were proposed.
\end{abstract}

Citation: Tetiana Yarotska, Svitlana Fedchuk. (2018) Foreign Income - Problems of Double Taxation. International Journal of Innovative Technologies in Economy. 8(20). doi: 10.31435/rsglobal_ijite/30112018/6210

Copyright: (C) 2018 Tetiana Yarotska, Svitlana Fedchuk. This is an open-access article distributed under the terms of the Creative Commons Attribution License (CC BY). The use, distribution or reproduction in other forums is permitted, provided the original author(s) or licensor are credited and that the original publication in this journal is cited, in accordance with accepted academic practice. No use, distribution or reproduction is permitted which does not comply with these terms.

Introduction. Ukrainians are not only actively employed abroad nowadays, but also participate in international movement of capital, goods and services. Personal income received abroad by individuals - Ukrainian tax residents must be declared and taxed in Ukraine. At the same time, the Ukrainian legislation stipulates that taxes paid abroad in the source country can be credited against Ukrainian tax liabilities to avoid the double taxation of the personal income of taxpayers, in case the Tax Convention on Income and on Capital is valid between Ukraine and the respective income source country. However, in practice, usually it is impossible to apply the Tax Convention on Income and on Capital as the official document confirming the individual's taxable income and the amount of tax paid abroad cannot be issued by the respective foreign tax authorities, or can be obtained in the unacceptable format, or the document is obtained with a delay. As a result, individuals - the Ukrainian tax residents may suffer because of double taxation of their foreign income in Ukraine. In the research the specific changes in the Tax Code of Ukraine were proposed. In addition, the unification of tax good standing confirmation was recommended based on significant changes in tax co-operation, which includes also the automatic exchange of financial information in tax matters.

Analysis, study, research. Taxation of personal foreign income in Ukraine depends on the tax status of the individual: tax resident or tax non-resident. Residents are liable for the personal income tax and military tax on their entire worldwide income. Non-residents are liable for taxes only on their Ukrainian sourced income.

A Ukrainian tax resident's taxable income includes any income received or accrued in Ukraine and/or abroad (e.g. employment income, dividends, interest, royalty, rental, investment income, inheritance, etc.). 
Foreign income has to be included into the total annual taxable income of Ukrainian tax residents and reported in the annual personal tax declaration. Income in foreign currency is recalculated into UAH at the official exchange rate of the National Bank of Ukraine on the date of its receipt. The declaration has to be filed with the Ukrainian tax office where the individual is registered in Ukraine by 30 April of the year following the reporting year. Tax is due by 31 July of the year following the reporting one. Payment must be made in UAH. The individual's foreign income is subject to an $18 \%$ personal income tax and $1.5 \%$ military tax.

How can taxes paid abroad be credited against Ukrainian tax liabilities? If the foreign income has been taxed abroad by the source country, the Ukrainian tax due may be decreased by the amount of tax credit allowed by an effective Tax Convention on Income and on Capital (Article 13.3 of Tax Code of Ukraine) [1]. The Ukrainian resident taxpayer can officially apply for an extension of the declaration filing deadline until 31 December of the year following the reporting year, if the documents for claiming a foreign tax credit from a foreign jurisdiction are not available by the standard Ukrainian filing deadline.

According to our research of real tax cases of Ukrainian tax residents, we determined that despite the significant number of effective Tax Conventions on Income and on Capital signed by Ukraine with other countries [2], sometimes it is impossible for individuals to obtain an official confirmation of the amounts of taxable base and the tax paid abroad, issued by the foreign tax authorities, in the format prescribed by the Tax Code of Ukraine. Unfortunately, the tax authorities of some states will not issue this document, or will issue it only as a digital certificate (e.g. in Spain, Italy, Switzerland, Germany, the UK, the USA and others). Also, obtaining of such certificate is problematic for individuals in the Russian Federation. To date, such official confirmation of tax base and tax paid abroad can be obtained in Czech Republic, Hungary, Belgium, Poland and some other states, which is beneficial, particularly, for many Ukrainians working there. According to our research, individuals - Ukrainian tax residents succeeded to obtain the official certificate with the required data of income received and personal income taxes paid in Romania and some other European countries. However, these documents were obtained with a significant delay, which caused the late filing of the Ukrainian tax declarations and late tax payments in Ukraine.

How foreign tax systems eliminate the double taxation of personal income in the same situation as described above?

We determined that in practice the tax authorities of many countries accept digital certificates, copies of tax returns, salary certificates as a sufficient confirmation of the income taxed abroad. In this respect, we recommend to follow the same approach in Ukraine and amend the Article 13 of the Tax Code of Ukraine accordingly. To confirm the individual's right for the credit of foreign tax in Ukraine to avoid the double taxation in Ukraine, the Ukrainian tax authorities should also be allowed to accept not only the official paper confirmation of the tax base and tax paid, issued by a foreign tax office, but other kinds of documents (e.g., a copy of the filed foreign tax declaration, bank confirmation of tax payment, foreign employer's certificates, digital certificates of tax good standing, etc.).

Going further, we would propose to unify documents confirming the taxable base and the tax payments of individuals in sight of better practical implementation of the Multilateral Convention on Mutual Administrative Assistance in Tax Matters, which is building a new co-operative environment worldwide, including, in particular, the EU and non-EU countries [3]. The unified official document, confirming taxable income and personal income taxes paid abroad, would also be beneficial for individuals in many states with respect to the implementation of Automatic Exchange of Financial Account Information in Tax Matters [4,5].

We determined another problem where the foreign income of a Ukrainian tax resident has been taxed by the source state with no effective Tax Convention on Income and on Capital with Ukraine, and the credit of this tax against Ukrainian tax due is not allowed at all [1]. As a result, the double taxation of that foreign income takes place in Ukraine. As this provision of Ukrainian law causes double taxation of individual`s foreign income in Ukraine, it is recommended to remove this discriminating clause from the Tax Code of Ukraine. It is worth to mention that tax law of many countries allows the elimination of double taxation in case of the absence of the respective valid Tax Convention on Income and on Capital (e.g., in Poland).

Conclusions. Based on the analysis of the practice of crediting taxes paid abroad by individuals against their personal income tax obligations in Ukraine, we have found the significant problem with obtaining proper foreign tax documents confirming tax base and tax payments of individuals in the foreign source states. In many European countries the obtaining of official documents, issued by tax authorities, is impossible, or is only available with an unacceptable format. 
In addition, in some cases the required documents were obtained with a delay, and at high additional costs. As a result, in practice the Ukrainian tax payers cannot use the effective Tax Conventions on Income and on Capital and their foreign income is a subject for a double taxation in Ukraine.

Considering the determined practical problem of the foreign tax base and tax payment confirmation, in our opinion, the mechanism of official tax base and tax payment confirmation should be unified worldwide. The problem becomes vaguer for the implementation of the automatic exchange of information in tax matters between jurisdictions.

\section{REFERENCES}

1. Tax Code of Ukraine. The Law of Ukraine dated 2 December 2010 \#2755-VI, with changes.

2. Лист ДФС України від 02.01.2018 № 78/7/99-99-01-02-02-17 "Щодо міжнародних договорів про уникнення подвійного оподаткування".

3. Лист ДФС України від 02.01.2018 № 77/7/99-99-01-02-02-17 "Про перелік країн, на які поширюється дія Конвенції про взаємну адміністративну допомогу в податкових справах".

4. Standard for Automatic Exchange of Financial Account Information in Tax Matters. OECD (2014), ISBN 978-92-64-21652-5, P. 29-30. Available in https://www.oecd-ilibrary.org/docserver/9789264216525en.pdf?expires $=1540549268 \&$ id=id $\&$ accname $=$ guest $\&$ checksum=70B32B314090A2803A80C24777B450 46

5. Standard for Automatic Exchange of Financial Account Information in Tax Matters: Implementation Handbook P. 100-102. Available in https://www.oecd.org/ctp/exchange-of-taxinformation/implementation-handbook-standard-for-automatic-exchange-of-financial-account-informationin-tax-matters.htm 